E3S Web of Conferences 1, 35004 (2013)

DOI: $10.1051 / \mathrm{e} 3$ sconf/20130135004

(C) Owned by the authors, published by EDP Sciences, 2013

\title{
A holistic approach to phosphate stabilization treatment of metal contaminated soil
}

\author{
M. Zupančič ${ }^{1}$ and P. Bukovec ${ }^{2}$ \\ ${ }^{1}$ Faculty of Chemistry and Chemical Technology, University of Ljubljana, Aškerčeva 5, 1000 Ljubljana, SLOVENIA, \\ marija.zupancic@fkkt.uni-lj.si \\ ${ }^{2}$ Faculty of Chemistry and Chemical Technology, University of Ljubljana, Aškerčeva 5, 1000 Ljubljana, SLOVENIA, \\ peter.bukovec@fkkt.uni-lj.si
}

\begin{abstract}
In our study we showed the importance of holistic approach to evaluation of chemical stabilization using phosphate amendments, where all aspects of chemical treatments were observed. An extensive evaluation of metal stabilization in contaminated soil and an evaluation of the leaching of phosphorus induced after treatment were performed. The soil from the former zinc smelter area in the Celje region, used in this study, was heavily polluted with $\mathrm{Zn}\left(34400 \pm 1500 \mathrm{mg} \mathrm{kg}^{-1}\right), \mathrm{Pb}\left(20400 \pm 1500 \mathrm{mg} \mathrm{kg}^{-1}\right)$, As $\left(950 \pm 10 \mathrm{mg} \mathrm{kg}^{-1}\right), \mathrm{Cu}\left(549 \pm 7 \mathrm{mg} \mathrm{kg}^{-1}\right)$ and $\mathrm{Cd}\left(158 \pm 4 \mathrm{mg} \mathrm{kg}^{-1}\right)$. The results of Toxicity Characteristic Leaching Procedure showed high mobility of $\mathrm{Zn}\left(540 \pm 25 \mathrm{mg} \mathrm{L}^{-1}\right), \mathrm{Pb}\left(12.7 \pm 0.5 \mathrm{mg} \mathrm{L}^{-1}\right)$ and $\mathrm{Cd}(2.9 \pm 0.1$ $\mathrm{mg} \mathrm{L}^{-1}$ ). To immobilize metals in the soil, mixtures of soil with phosphate (variable molar ratio of hydroxyapatite and phosphoric acid) were prepared with a constant molar $\mathrm{Pb}: \mathrm{P}$ ratio of 1:10. Hydroxyapatite as the only source of phosphate showed a high stabilization efficiency, above all for $\mathrm{Pb}$ with over $97 \%$ of primary acetic acid leachable $\mathrm{Pb}$ immobilized. The addition of phosphoric acid as a source of phosphate resulted in an increase in leaching of phosphorus up to $50 \mathrm{mg} \mathrm{L}^{-1}$ in water extracts. Lime that was also added in some stabilization mixtures increased the stabilization efficiency of phosphate and also decreased the treatment-induced phosphate leaching. To evaluate the long-term stability of immobilization, leaching of metals and phosphorus was assessed in a column experiment with synthetic precipitation that in general showed steady decrease in leachability of metals and phosphorus with quite high cumulative $\mathrm{Zn}$ and $\mathrm{Cd}$ concentrations in leachates of soil sample and extremely high (30\% of total added $\mathrm{P}$ concentration) cumulative $\mathrm{P}$ concentrations in leachates of mixture with highest amount of added phosphoric acid and no addition of lime.
\end{abstract}

Key words: Chemical stabilization, contaminated soil, lime, metal, phosphate, remediation

\section{Introduction}

Chemical stabilization of metal contaminated soil is sustainable and economically acceptable remediation technology. By chemical stabilization, mobile metal chemical species are transformed into less mobile ones, thus reducing the risk of heavy metal transport from contaminated soil to the ground and surface waters, and also decreasing the risk of the potential bioavailability/phytoavailability of metals. Contaminant immobilizing amendments decrease metal mobility by inducing various sorption processes: adsorption to mineral surfaces, formation of stable complexes, surface precipitation and ion exchange. Phosphate treatment was proven to be an efficient approach to immobilizing metals in contaminated soil and waste media (Bolan et al.,
2003; Miretzky and Fernandez-Cirelli, 2008; Park et al., 2011). Because of water resource euthrophication and the need for water protection strategies, estimation of diffuse phosphorus (P) leaching losses from soil is an important issue. Although many studies dealing with the phosphate treatment of metal-contaminated soil and wastes were reported, treatment-induced leaching of $\mathrm{P}$ has been largely overlooked.

In our study, heavily polluted soil from the former zinc smelter area in the Celje region, Slovenia, was used with the aim to find the equilibrium between all aspects (parameters) of phosphate based treatments of metal contaminated soil and to show the importance of such holistic approach. An extensive study on different stabilization mixtures, dealing with two phosphate sources and lime, was performed. All mixtures have the 
Table 1. Mean TCLP concentrations (in $\mathrm{mg} \mathrm{kg}^{-1}, \mathrm{~N}=3$ ) of metals in soil and soil mixtures with different $\mathrm{HA}: \mathrm{H}_{3} \mathrm{PO}_{4}: \mathrm{CaO}$ molar ratios and metal stabilization efficiency (in \%) of mixtures, except for As where destabilization is presented as the n-times increase in leachability

\begin{tabular}{|c|c|c|c|c|c|c|c|c|c|c|c|c|}
\hline \multirow[b]{2}{*}{$\begin{array}{c}\text { mixture } \\
\mathrm{n}(\mathrm{HA}): \mathbf{n}\left(\mathrm{H}_{3} \mathrm{PO}_{4}\right): \mathbf{n}(\mathrm{CaO})\end{array}$} & \multicolumn{2}{|c|}{$\mathrm{Ni}$} & \multicolumn{2}{|c|}{$\mathrm{Cu}$} & \multicolumn{2}{|c|}{$\mathrm{Zn}$} & \multicolumn{2}{|l|}{ As } & \multicolumn{2}{|c|}{ Cd } & \multicolumn{2}{|c|}{$\mathbf{P b}$} \\
\hline & $\begin{array}{c}\text { TCLP } \\
\text { conc. } \\
{\left[\mathrm{mg} \mathrm{L}^{-1}\right]}\end{array}$ & $\begin{array}{l}\text { stab. } \\
{[\%]}\end{array}$ & $\begin{array}{c}\text { TCLP } \\
\text { conc. } \\
{\left[\mathrm{mg} \mathrm{L}^{-1}\right]}\end{array}$ & $\begin{array}{l}\text { stab. } \\
{[\%]}\end{array}$ & $\begin{array}{c}\text { TCLP } \\
\text { conc. } \\
{\left[\mathrm{mg} \mathrm{L}^{-1}\right]}\end{array}$ & $\begin{array}{l}\text { stab. } \\
{[\%]}\end{array}$ & $\begin{array}{c}\text { TCLP } \\
\text { conc. } \\
{\left[\mathrm{mg} \mathrm{L}^{-1}\right]}\end{array}$ & $\begin{array}{l}\text { stab. } \\
{[\%]}\end{array}$ & $\begin{array}{c}\text { TCLP } \\
\text { conc. } \\
{\left[\mathrm{mg} \mathrm{L}^{-1}\right]}\end{array}$ & $\begin{array}{l}\text { stab. } \\
{[\%]}\end{array}$ & $\begin{array}{c}\text { TCLP } \\
\text { conc. } \\
{\left[\mathrm{mg} \mathrm{L}^{-1} \text { ] }\right.}\end{array}$ & $\begin{array}{l}\text { stab. } \\
{[\%]}\end{array}$ \\
\hline Soil & 0,11 & & 0,33 & & 437 & & 0,02 & & 2,9 & & 13 & \\
\hline (1:0):0 & 0,09 & 17 & 0,11 & 65 & 226 & 48 & 1,4 & 90 & 1,3 & 55 & 0,3 & 97 \\
\hline$(1: 0.5): 0$ & 0,12 & destab. & 0,16 & 51 & 285 & 35 & 1,3 & 85 & 1,5 & 46 & 0,5 & 96 \\
\hline (1:1):0 & 0,13 & destab. & 0,18 & 46 & 277 & 37 & 1,3 & 85 & 1,3 & 53 & 0,4 & 97 \\
\hline (1:2):0 & 0,15 & destab. & 0,16 & 51 & 270 & 38 & 1,6 & 101 & 1,4 & 53 & 0,2 & 98 \\
\hline (1:1):1 & 0,07 & 34 & 0,07 & 78 & 152 & 65 & 1,0 & 62 & 1,2 & 58 & 1,1 & 91 \\
\hline (1:1):2 & 0,05 & 54 & 0,03 & 91 & 31 & 93 & 0,2 & 16 & 0,6 & 78 & 0,9 & 93 \\
\hline (1:1):3 & 0,04 & 63 & 0,02 & 94 & 10 & 98 & 0,1 & 5,5 & 0,3 & 90 & 0,3 & 98 \\
\hline (1:2):1 & 0,07 & 35 & 0,07 & 77 & 103 & 76 & 1,4 & 90 & 1,0 & 67 & 0,9 & 93 \\
\hline (1:2):2 & 0,05 & 53 & 0,03 & 90 & 45 & 90 & 0,4 & 28 & 0,9 & 69 & 0,7 & 95 \\
\hline$(1: 2): 3$ & 0,04 & 67 & 0,01 & 96 & 2 & 100 & 0,1 & 6,3 & 0,1 & 96 & 0,1 & 99 \\
\hline
\end{tabular}

same amount of added total $\mathrm{P}$, but varying amount of both phosphate additions. The mobility of metals and $\mathrm{P}$ was studied and evaluated in all parts of our study. The time-dependent leaching characteristic of metals and $\mathrm{P}$ for soil and all mixtures was evaluated by a column experiment.

\section{Materials and Methods}

The sub-samples of soil collected were combined into a representative composite sample and pre-treated according to SIST ISO 11464:1996 (dried in air, crushed and passed through the 2-mm sieve). The $\mathrm{pH}$ values of the soil sample and its mixtures were determined in a $0.01 \mathrm{M} \mathrm{CaCl}_{2}$ suspension (liquid to soil ratio 5:1). To determine the total metal concentration in soil samples, approximately $0.5 \mathrm{~g}$ of air-dried soil sample was digested in $5 \mathrm{~mL}$ of aqua regia (SIST ISO 11466:1996) at $473 \mathrm{~K}$ for 4 hours. To immobilize metals in soil, soil mixtures with phosphate additions (constant molar $\mathrm{Pb}: \mathrm{P}$ ratio of 1:10 in all mixtures) were prepared. The phosphate additions were prepared from two phospate sources with quite different solubility characteristics, $\mathrm{H}_{3} \mathrm{PO}_{4}$ and hydroxyapatite (HA), with varying compositions. To regulate the $\mathrm{pH}$, lime was also used in the stabilization mixtures (stated as molar ratio to total phosphate). The mobility of metals in soil and prepared mixtures was evaluated according to the Toxicity Characteristic Leaching Procedure - TCLP (USEPA, SW-846: Test Methods for Evaluating Solid Waste, Physical/Chemical Methods, Analytical Method 1311: Toxicity Characteristic Leaching Procedure). Twenty $\mathrm{mL}$ of 0.11 $\mathrm{M}$ acetic acid were added to $1.000 \pm 0.005 \mathrm{~g}$ of air-dried soil samples. Samples were shaken for 20 hours at 150 rpm, centrifuged, decanted and filtered through the membrane filter of $0.45 \mu \mathrm{m}$ pore size. Treatment-induced leaching of $\mathrm{P}$ was evaluated by the phosphate concentration in water extracts $(\mathrm{S} / \mathrm{L}=1: 10)$ of soil mixtures.
The time-dependent leaching characteristics of metals and phosphate for all mixtures were evaluated with a column experiment. The columns (PE, $\Phi=25 \mathrm{~mm}$, $\mathrm{h}=130 \mathrm{~mm}$ ) were filled with $65.000 \pm 0.005 \mathrm{~g}$ of soil or mixture ( $\mathrm{N}=3$ for all samples). The leaching of mixtures with average annual amount of synthetic precipitation (pH 4.2) of $1300 \mathrm{~mm}$ was simulated. An amount of precipitation was divided into 40 portions that were poured into columns every two days. The first ten leachings were performed with one portion of precipitation followed with fifteen leachinhg with double potions of leachate. The concentration of metals and $\mathrm{P}$ in all prepared samples were analysed by ICP-MS.

\section{Results and Discussion}

Total metal determination showed that the soil was heavily polluted with $\mathrm{Zn}\left(34400 \pm 1500 \mathrm{mg} \mathrm{kg}^{-1}\right), \mathrm{Pb}$ $\left(20400 \pm 1500 \mathrm{mg} \mathrm{kg}^{-1}\right)$, As $\left(950 \pm 10 \mathrm{mg} \mathrm{kg}^{-1}\right), \mathrm{Cu}$ $\left(549 \pm 7 \mathrm{mg} \mathrm{kg}^{-1}\right)$ and $\mathrm{Cd}\left(158 \pm 4 \mathrm{mg} \mathrm{kg}^{-1}\right)$. The results of TCLP showed high mobility of $\mathrm{Zn}\left(540 \pm 25 \mathrm{mg} \mathrm{L}^{-1}\right)$, $\mathrm{Pb}\left(12.7 \pm 0.5 \mathrm{mg} \mathrm{L}^{-1}\right)$ and $\mathrm{Cd}\left(2.9 \pm 0.1 \mathrm{mg} \mathrm{L}^{-1}\right)$.

Table 1 presents the mean TCLP concentrations of metals in soil and in soil mixtures (in $\mathrm{mg} \mathrm{kg}^{-1}$ ) for different $\mathrm{HA}: \mathrm{H}_{3} \mathrm{PO}_{4}: \mathrm{CaO}$ molar ratios and the metal stabilization efficiencies of mixtures, except for As, where destabilization is presented as the n-times increase in leachability. Addition of HA significantly decreased the mobility of metals, especially of $\mathrm{Cu}, \mathrm{Zn}, \mathrm{Cd}$ and $\mathrm{Pb}$ $(65 \%, 48 \%, 55 \%$ and $97 \%$, respectively, of the primary TCLP leachable concentration), increased the mobility of As, increased the water leachable phosphate concentration and decreased $\mathrm{pH}$ of the mixture (Table 2). An addition of phosphoric acid decreased the stabilization efficiency observed on addition of HA (probably due to a decrease in $\mathrm{pH}$ of the mixtures as a consequence of the addition of phosphoric acid). At higher amounts of added phosphoric acid, the 
stabilization efficiency overcame the impact of lower $\mathrm{pH}$. A great increase in mobility of As was observed after the addition of phosphoric acid, but the highest As TCLP concentration of $1.56 \mathrm{mg} \mathrm{L}^{-1}$ was still far below the stated TCLP value of $5 \mathrm{mg} \mathrm{L}^{-1}$. Arsenic is present in the environment mainly as oxyanions, and similarities between phosphate and arsenate obviously resulted in the leaching of As as a consequence of phosphate addition. Both oxyanions compete for the same adsorption sites and the results suggest that the retardation factor for arsenate is lower than for phosphate. An increase in the stabilization efficiency of $\mathrm{Co}, \mathrm{Ni}$ and $\mathrm{Zn}$ was observed after the addition of lime with high decrease in water leachable $\mathrm{P}$ concentrations and increase of $\mathrm{pH}$ of soil mixtures.

Leaching of soil with synthetic precipitation showed an increase in leachability of $\mathrm{Pb}, \mathrm{Cd}$ and $\mathrm{Ni}$ at the beginning of the experiment up to $1.6 \mathrm{mg} \mathrm{L}^{-1}, 2.5 \mathrm{mg} \mathrm{L}^{-1}$ and $0.2 \mathrm{mg} \mathrm{L}^{-1}$, respectively, followed with sharply decrease after addition of $230 \mathrm{~mm}$ of precipitation. Concentrations of $\mathrm{As}, \mathrm{P}$ and $\mathrm{Cu}$ in soil leachates were less than $0.002 \mathrm{mg} \mathrm{L}^{-1}, 0.05 \mathrm{mg} \mathrm{L}^{-1}$ and $0.02 \mathrm{mg} \mathrm{L}^{-1}$, respectively, during all irrigation period. Cumulative concentration of $\mathrm{Zn}, \mathrm{Pb}, \mathrm{Cd}$ and $\mathrm{Ni}$ in leachates of soil sample represents $5.0 \%, 0.044 \%, 6.4 \%$ and $6.3 \%$, respectively, of total metal concentration.

At first four mixtures, where no lime was added, sharp decrease in leachability of all elements was observed at the beginning of irrigation, followed by a slow decrease till the end of the experiment. The concentrations of elements in leachates of mixtures with added lime were much lower compared to the first four mixtures.

Table 2. Concentrations of water leachable phosphorus in water extracts in $\mathrm{mg} \mathrm{L}^{-1} \pm$ standard deviation $(\mathrm{N}=3)$ and $\mathrm{pH}$ of soil and of soil mixtures.

\begin{tabular}{ccc}
$\begin{array}{c}\text { mixture } \\
\mathbf{n}(\mathbf{H A}): \mathbf{n}\left(\mathbf{H}_{3} \mathbf{P O} \mathbf{)}\right): \mathbf{n}(\mathbf{C a O})\end{array}$ & $\begin{array}{c}\text { P conc. } \\
{\left[\mathbf{m g ~ L}^{-\mathbf{1}}\right]}\end{array}$ & $\mathbf{p H}$ \\
\hline Soil & $<0.05$ & 6.43 \\
$(1: 0): 0$ & $5.3 \pm 0.9$ & 5.45 \\
$(1: 0.5): 0$ & $11 \pm 2$ & 5.05 \\
$(1: 1): 0$ & $22 \pm 3$ & 4.86 \\
$(1: 2): 0$ & $50 \pm 10$ & 4.81 \\
$(1: 1): 1$ & $0.7 \pm 0.2$ & 7.61 \\
$(1: 1): 2$ & $0.26 \pm 0.06$ & 8.3 \\
$(1: 1): 3$ & $0.06 \pm 0.02$ & 12.2 \\
$(1: 2): 1$ & $2.9 \pm 0.9$ & 7.24 \\
$(1: 2): 2$ & $0.09 \pm 0.03$ & 8.67 \\
$(1: 2): 3$ & $<0.05$ & 9.54 \\
\hline
\end{tabular}

Sharp increase of leachability of $\mathrm{Pb}$ and $\mathrm{Cd}$ was observed up to leaching with $300 \mathrm{~mm}$ of precipitations, followed by a sharp decrease till the end of irrigation. These trends were observed specially at mixture $n(\mathrm{HA}): n\left(\mathrm{H}_{3} \mathrm{PO}_{4}\right): n(\mathrm{CaO})=(1: 1): 3$ for $\mathrm{Pb}$ (up to $0.1 \mathrm{mg}$
$\left.\mathrm{L}^{-1}\right)$ and at mixtures $n(\mathrm{HA}): n\left(\mathrm{H}_{3} \mathrm{PO}_{4}\right): n(\mathrm{CaO})=(1: 1): 1$ and $n(\mathrm{HA}): n\left(\mathrm{H}_{3} \mathrm{PO}_{4}\right): n(\mathrm{CaO})=(1: 2): 1$ for $\mathrm{Cd}$ (up to $\left.0.015 \mathrm{mg} \mathrm{L}^{-1}\right)$. An addition of HA decreased the cumulative $\mathrm{Cd}$ and $\mathrm{Pb}$ concentration on $0.87 \%$ and on $7 \cdot 10^{-4} \%$, respectively, of total metal concentration. With addition of HA cumulative $\mathrm{Zn}$ leachate concentration reached $0.8 \%$ of total $\mathrm{Zn}$ concentration. An addition of $\mathrm{H}_{3} \mathrm{PO}_{4}$ increase the cumulative $\mathrm{P}$ leachate concentration from $69 \mathrm{mg} \mathrm{kg}^{-1}$ (2.3\% of total added $\mathrm{P}$ concentration) in mixture with added HA on $963 \mathrm{mg} \mathrm{kg}^{-1}$ (30.7\% of total added $\mathrm{P}$ concentration) in mixture with the highest $\begin{array}{lllll}\text { amount of added } & \mathrm{H}_{3} \mathrm{PO}_{4} & \text { (mixture }\end{array}$ $\left.n(\mathrm{HA}): n\left(\mathrm{H}_{3} \mathrm{PO}_{4}\right): n(\mathrm{CaO})=(1: 2): 0\right)$. In mixtures with added lime cumulative leachate $\mathrm{P}$ concentration drastically decreased down to $0.083 \%$ of total added $\mathrm{P}$ amount. Steady increase in leachability of $\mathrm{P}$ was observed for both mixtures with lowest amount of added lime $\left(n(\mathrm{HA}): n\left(\mathrm{H}_{3} \mathrm{PO}_{4}\right): n(\mathrm{CaO})=(1: 1): 1\right.$ and $n(\mathrm{HA})$ : $\left.n\left(\mathrm{H}_{3} \mathrm{PO}_{4}\right): n(\mathrm{CaO})=(1: 2): 1\right)$ up to $1.2 \mathrm{mg} \mathrm{L}^{-1}$ (cumulative leachate $\mathrm{P}$ concentration of $0.29 \%$ and $0.24 \%$, respectively, of total added $\mathrm{P})$.

The mixture $\left(n(\mathrm{HA}): n\left(\mathrm{H}_{3} \mathrm{PO}_{4}\right): n(\mathrm{CaO})=(1: 2): 3\right.$ with $\mathrm{pH} 9.45$ showed the lowest metal and $\mathrm{P}$ mobility in first part of our study (Table 1 and Table 2). Results of the column experiment showed that during all irrigation period the concentrations of $\mathrm{Zn}, \mathrm{Cd}, \mathrm{Ni}$ and $\mathrm{Co}$ in leachates of this mixture were below limit of detection, whereas the cumulative amount of leached $\mathrm{Cu}, \mathrm{As}, \mathrm{Pb}$ and $P$ was $0.42 \mathrm{mg} \mathrm{kg}^{-1}, 0.059 \mathrm{mg} \mathrm{kg}^{-1}, 0.045 \mathrm{mg} \mathrm{kg}^{-1}$ and $2.4 \mathrm{mg} \mathrm{kg}^{-1}$, respectively.

$\mathrm{pH}$ of leachates varied from 4.9 at mixture $n(\mathrm{HA}): n\left(\mathrm{H}_{3} \mathrm{PO}_{4}\right): n(\mathrm{CaO})=(1: 2): 0$ to 8.4 at mixture $n(\mathrm{HA}): n\left(\mathrm{H}_{3} \mathrm{PO}_{4}\right): n(\mathrm{CaO})=(1: 1): 3$ with no significant changes during all irrigation period.

\section{Conclusion}

The ultimate goal of each soil remediation should be the full restoration of the capability of soil to fulfil its environmental role. Therefore, detailed attention should be paid to the equilibrium between the benefits of metal-stabilization efficiency on the one hand, and the treatment-induced leaching of stabilization agents on the other. Furthermore, the long-term stability of metal immobilization should be evaluated for each metal stabilization study. Although the use of phosphate amendments for the stabilization of metal-contaminated soil and waste materials has been widely studied, studies of the leaching of $\mathrm{P}$ itself as a consequence of phosphate treatment are generally overlooked.

The results of our study clearly show the importance of holistic approach to phosphate based metal stabilization studies where all aspects of chemical treatments should be observed and evaluated.

\section{Acknowledgements}

This research study was financially supported by the Ministry of Higher Education, Science and Technology (P1-0134) of the Republic of Slovenia.

\section{References}



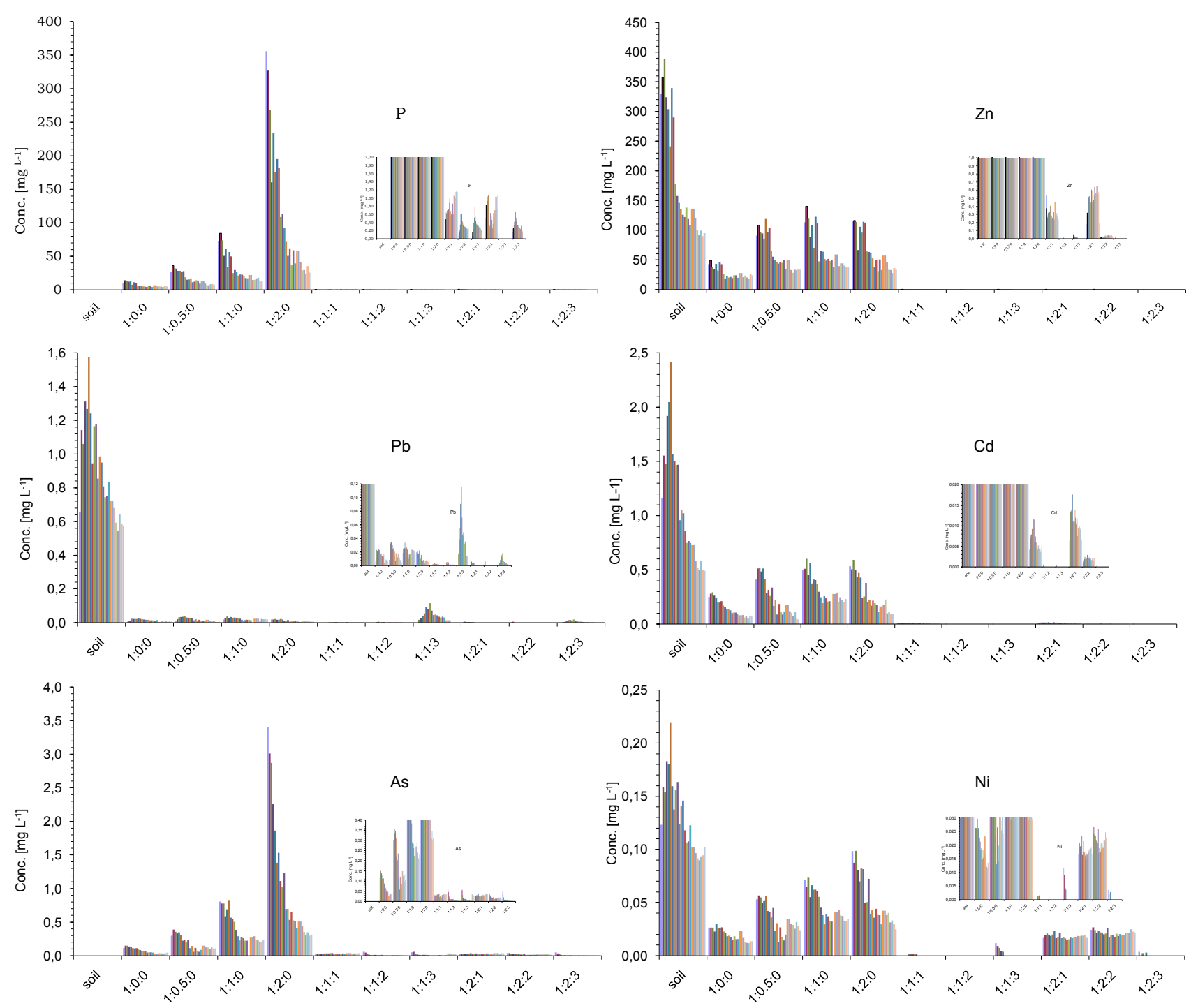

\begin{tabular}{|c|c|c|c|c|c|c|c|c|c|c|c|c|}
\hline & & $97.5 \mathrm{~mm}$ & & & & $=227.5 \mathrm{~mm}$ & & $292.5 \mathrm{~mm}$ & $1170 \mathrm{~mm}$ & $1235 \mathrm{~mm}$ & $=455 \mathrm{~mm}$ & \\
\hline$\square 5$ & $=650 \mathrm{~mm}$ & $=715 \mathrm{~mm}$ & $=780 \mathrm{~mm}$ & $=845 \mathrm{~mm}$ & $=910 \mathrm{~mm}$ & ॥ $975 \mathrm{~mm}$ & $=1040 \mathrm{~mm}$ & $=1105 \mathrm{~mm}$ & $\square 1170 \mathrm{~mm}$ & $=1235 \mathrm{~mm}$ & $=1300 \mathrm{~mm}$ & \\
\hline
\end{tabular}

Fig. 1. Metal concentrations (mean, $\mathrm{N}=3$ ) in leachates collected after leaching of mixtures with annual amount of synthetic precipitation ( $\mathrm{pH} 4.2)$

\section{References}

Miretzky P, Fernandez-Cirelli A. Phosphates for $\mathrm{Pb}$ immobilization in soils: a review. Environ Chem Lett 2008; 6:121-133.

Park JH, Bolan NS, Megharaj M, Naidu R. Comparative value of phosphate sources on the immobilization of lead, and leaching of lead and phosphorus in lead contaminated soils. Sci Total Environ 2011; 409, 853-860.

Bolan NS, Adriano DC, Naidu R. Role of phosphorus in (im)mobilization and bioavailability of heavy metals in the soil-slant system. Rev Environ Contam Toxicol 2003; 177: 1-44. 